\title{
Pseudomonas pseudoalcaligenes subsp. konjaci subsp. nov., the Causal Agent of Bacterial Leaf Blight of Konjac (Amorphophalus konjac Koch.)
}

\author{
M. GOTO \\ Faculty of Agriculture, Shizuoka University, 836 Ohya, Shizuoka, 422 Japan
}

\begin{abstract}
A bacterial disease characterized by the development of rectangular lesions on the leaves of konjac (Amorphophalus konjac Koch.) is described. The size of the lesions increased rapidly under humid conditions, resulting in leaf blight. Leaves with severe blight drooped and finally decayed. The disease was identified from the symptoms as bacterial leaf blight on the basis of the descriptions made by Uyeda in 1910. The causal agent was, however, different from Xanthomonas conjaci (Uyeda) Burkholder in many respects and was found to be a new subspecies of Pseudomonas pseudoalcaligenes based on the results of a direct comparison of pathological and biochemical properties. The name Pseudomonas pseudoalcaligenes subsp. konjaci subsp. nov. is proposed for the new subspecies, and strain K2 (= ATCC $33996=$ PDDCC 7733) is designated the type strain.
\end{abstract}

A bacterial disease that is prevalent on the foliage of the konjac plant (Amorphophalus kon$j a c)$, whose root tubers are processed for the Japanese food product called konjac, has been described in textbooks of plant pathology as a bacterial leaf blight caused by Xanthomonas conjaci (Uyeda) Burkholder. However, until now no information about this disease except the original report of Uyeda (17) has been available. No cultures of the causal agent have been maintained in any collection of plant-pathogenic bacteria. Therefore, the causal agent was designated species incertae sedis in Bergey's Manual of Determinative Bacteriology, 8th ed., and was not listed on the Approved Lists of Bacterial Names (12) or the Pathovar List of Plant Pathogenic Bacteria (5). Thus, the pathogen of the disease of konjac has been left without an acceptable name despite its economic importance to konjac growers.

In a preliminary study in 1978 the konjac bacterium was compared with several pathovars of Pseudomonas syringae and Pseudomonas andropogonis. The konjac strains appeared to be distinctly different from these other bacteria in their biochemical and pathological characteristics. In contrast, some of the descriptions in the literature suggest a relationship between the konjac bacterium and the nonfluorescent organism Pseudomonas pseudoalcaligenes with regard to important biochemical properties, especially the ability to utilize glucose as a sole source of carbon. Therefore, I compared cultures of the konjac bacterium with cultures of Pseudomonas alcaligenes, $P$. pseudoalcali- genes, and $P$. pseudoalcaligenes subsp. citrulli, a newly described plant pathogen (10).

In this paper I present the results of a study of these four bacteria and give a revised description of the bacterium responsible for bacterial leaf blight of konjac.

\section{MATERIALS AND METHODS}

Bacterial strains. The pseudomonads included in this study are listed in Table 1 . A total of 17 strains of the konjac bacterium were isolated from small, watersoaked lesions of diseased leaves; these strains included 7 strains isolated in Shizuoka Prefecture and 10 strains isolated in Gumma Prefecture. The strains of $P$. alcaligenes, $P$. pseudoalcaligenes, and $P$. pseudoalcaligenes subsp. citrulli used as reference strains were provided by the Culture Collection of the Institute for Fermentation, Osaka, Japan, and the Plant Diseases Division Culture Collection, Auckland, New Zealand. All strains were grown on yeast extract-peptone (YP) agar slants $(0.5 \%$ yeast extract, $1.0 \%$ peptone, $1.5 \%$ agar) and were maintained at $4^{\circ} \mathrm{C}$ for routine work.

To isolate the konjac bacterium, leaves with newly formed lesions were collected, and the diseased tissues with a water-soaked appearance were cut into pieces approximately $5 \mathrm{~mm}^{2}$. The surface of each piece was sterilized by dipping the piece into $70 \%$ alcohol for $1 \mathrm{~s}$. After the tissues were washed once in sterile water, they were crushed with a glass rod in a test tube containing $2 \mathrm{ml}$ of $1 \%$ peptone water. A loopful of the resulting suspension was streaked onto YP agar plates. After 2 to 3 days at $28^{\circ} \mathrm{C}$, white, round colonies were transferred to YP agar slants.

Pathogenicity. (i) Konjac. Tubers of $A$. konjac cv. native aoguki were planted in pots (diameter, $15 \mathrm{~cm}$ ) and grown in a greenhouse at 20 to $35^{\circ} \mathrm{C}$. When the leaves were fully expanded (in July), bacterial suspensions were sprayed onto the plants either before or 
after the leaf surfaces were wounded with a needle by puncturing. Bacterial suspensions were prepared by washing cells from 24- to 48-h YP agar slants into distilled water and adjusting the concentration to about $10^{8}$ cells per $\mathrm{ml}$, as determined by optical density. The inoculated plants were maintained in a mist chamber for $24 \mathrm{~h}$ and then transferred to a greenhouse, where disease development was monitored.

(ii) Cucurbitaceous plants. Watermelon (Citrullus lanatus cv. kinkisuika), cucumber (Cucumis sativus cv. okinmegami), muskmelon (Cucumis melo cv. purinsumeron), and pumpkin (Cucurbita maxima cv. ebisu) were used. Seedlings were grown in pots (diameter, $15 \mathrm{~cm}$ ), and plants were inoculated as described above. After inoculation the procedures described above for the konjac plant study were followed.

Bacteriological properties. Morphological measurements were made with a light microscope after staining with Ziehl carbolfuchsin (13). Poly- $\beta$-hydroxybutyrate was detected by staining 3-day-old YP-fructose agar cultures with sudan black B (9). The modified Yamanaka silver staining method (11) was used for flagellar staining.

Tests for catalase, amino acid decarboxylase, amylases, lipase (Tween 80), urease and oxidase, reduction of $\mathrm{KNO}_{3}$, production of acetylmethylcarbinol, 2ketogluconate, indole, and $\mathrm{H}_{2} \mathrm{~S}$ were performed as described by Cowan and Steel (3). Phenylalanine deaminase was tested (3) by using 2-day-old phenylalanine agar slant cultures. Tests for the litmus milk reaction, gelatin liquefaction, methyl red, and growth inhibition by $\mathrm{KCN}$, as well as the Hugh-Leifson test and the esculin hydrolysis test, were also performed as described by Cowan and Steel (3). The methods described by Dye (4) were used to test for the utilization of asparagine as a sole source of carbon and nitrogen and tolerance to $\mathrm{NaCl}$. The production of reducing substances from sucrose, arginine dihydrolase, and levan formation were tested by methods described previously (9). Utilization of carbon sources was tested in the basal media developed by Ayers et al. (9) and by Starr (15). Denitrification was tested by the method of Stanier et al. (14). Fluorescence was tested on King medium B (9).

Guanine-plus-cytosine content of deoxyribonucleic acid. Deoxyribonucleic acid was isolated and purified by the method of Marmur (7). The guanine-pluscytosine content was determined spectrometrically by the method of Ulitzur (16).

\section{RESULTS}

Bacteriological properties. The morphological, physiological, and biochemical characteristics of the konjac bacterium are summarized in Tables 2 and 3, where they are compared with the characteristics of the other pseudomonads included in this study.

The konjac bacterium was rod shaped with a single polar flagellum (Fig. 1) and gram negative. Growth of this bacterium on YP agar plates was relatively slow, and its colonies closely resembled those of $P$. alcaligenes, $P$. pseudoalcaligenes, and $P$. pseudoalcaligenes subsp. citrulli in being white, round, transparent, smooth, and slightly convex. The colonies were 0.8 to $1.0 \mathrm{~mm}$ in diameter within $48 \mathrm{~h}$ and 2 to $3 \mathrm{~mm}$ in diameter within 5 days at $28^{\circ} \mathrm{C}$. The konjac bacterium was characterized by a positive urease reaction and the production of a watersoluble brown pigment. A strong urease reaction was observed from 24 to $48 \mathrm{~h}$. A mild urease reaction was also detected in $P$. pseudoalcaligenes subsp. citrulli, but no urease reaction was detected in $P$. alcaligenes and $P$. pseudoalcaligenes. The konjac strains turned various agar media (King medium B, YP agar, potato-glucose agar) deep brown in 3 to 5 days. The growth of the konjac bacterium in YP broth at $41^{\circ} \mathrm{C}$ was relatively poor compared with the other bacte-

TABLE 1. Pseudomonas strains included in this study

\begin{tabular}{|c|c|c|c|}
\hline Taxon & Strain(s) & History $^{a}$ & Habitat \\
\hline Konjac bacterium & $\begin{array}{l}\mathrm{K} 1, \mathrm{~K} 2^{\mathrm{T}}, \mathrm{K} 3, \mathrm{~K} 4, \mathrm{~K} 5, \\
\mathrm{~K} 6, \mathrm{~K} 7^{b}\end{array}$ & Goto & Konjac \\
\hline Konjac bacterium & $\begin{array}{l}7901,7904,7907,7910 \\
7913,7916,7919,7923 \\
7925,7928^{\circ}\end{array}$ & Hayashi & Konjac \\
\hline$P$. alcaligenes & IFO $4^{\mathrm{T}}\left(=\right.$ ATCC $\left.14909^{\mathrm{T}}\right)$ & ATCC $\rightarrow$ Yabuuchi $\rightarrow$ IFO & Water \\
\hline P. pseudoalcaligenes & IFO $5^{\mathrm{T}}\left(=\right.$ ATCC $\left.17440^{\mathrm{T}}\right)$ & ATCC $\rightarrow$ Yabuuchi $\rightarrow$ IFO & Sinus drainage \\
\hline $\begin{array}{l}\text { P. pseudoalcaligenes } \\
\text { subsp. citrulli }\end{array}$ & PDDCC $6521^{d}$ & Schaad $\rightarrow$ PDDCC & Watermelon \\
\hline $\begin{array}{l}P . \text { pseudoalcaligenes } \\
\text { subsp. citrulli }\end{array}$ & PDDCC 6522 & Schaad $\rightarrow$ PDDCC & Watermelon \\
\hline
\end{tabular}

${ }^{a}$ Goto, M. Goto, Shizuoka University, Shizuoka, Japan; Hayashi, N. Hayashi, Gumma Agricultural Experiment Station, Gumma, Japan; ATCC, American Type Culture Collection, Rockville, Md.; Yabuuchi, E. Yabuuchi, Kansai Medical College, Osaka, Japan; IFO, Institute for Fermentation, Osaka, Japan; Schaad, N. W. Schaad, University of Georgia, Athens; PDDCC, Plant Diseases Division Culture Collection, Auckland, New Zealand. The arrows indicate route of culture.

${ }^{b}$ Isolated by M. Goto.

${ }^{c}$ Isolated by N. Hayashi.

${ }^{d}$ Isolated by N. W. Schaad. 
TABLE 2. Phenotypic characteristics of the konjac bacterium, $P$. alcaligenes, $P$. pseudoalcaligenes, and $P$. pseudoalcaligenes subsp. citrulli

\begin{tabular}{|c|c|c|c|c|}
\hline Character & $\begin{array}{l}\text { Konjac } \\
\text { bacterium } \\
(n=17)\end{array}$ & $\begin{array}{c}P . \\
\text { alcaligenes } \\
(n=1)\end{array}$ & $\begin{array}{l}P . \text { pseudo- } \\
\text { alcaligenes } \\
\quad(n=1)\end{array}$ & $\begin{array}{c}P \text {. pseudo- } \\
\text { alcaligenes } \\
\text { subsp. citrulli } \\
(n=2)\end{array}$ \\
\hline Gram stain & $-a$ & - & - & - \\
\hline Motility & + & + & + & + \\
\hline Flagellum $^{b}$ & Polar & Polar & Polar & Polar \\
\hline Poly- $\beta$-hydroxybutyrate accumulation & + & - & - & + \\
\hline Aerobic growth & + & + & + & + \\
\hline Catalase reaction & + & + & + & + \\
\hline Kovacs oxidase & + & + & + & + \\
\hline Oxidation/fermentation test & 0 & 0 & 0 & 0 \\
\hline Growth at $41^{\circ} \mathrm{C}$ & $+(\mathrm{d})$ & + & + & + \\
\hline Growth at $4^{\circ} \mathrm{C}$ & - & - & - & - \\
\hline Growth factor required & - & - & - & - \\
\hline Utilization of arginine as $\mathrm{C}$ source & - & - & + & - \\
\hline Utilization of betaine as $C$ source & - & - & + & - \\
\hline Utilization of asparagine as $\mathrm{C}$ and $\mathrm{N}$ sources & + & - & - & - \\
\hline Pigmentation on King medium $\mathrm{B}$ & Brown & - & - & - \\
\hline Nitrate reduction & + & + & + & + \\
\hline Denitrification & - & - & - & - \\
\hline Levan formation & - & - & - & - \\
\hline Arginine dihydrolase & - & $+(\mathrm{d})$ & $+(\mathrm{d})$ & - \\
\hline Gelatin liquefaction & - & \pm & - & \pm \\
\hline Starch hydrolysis & - & - & - & - \\
\hline Litmus milk & Alk & Alk & Alk & Alk \\
\hline Tween 80 hydrolysis & + & + & - & + \\
\hline $\mathrm{H}_{2} \mathrm{~S}$ production & + & + & $+(w)$ & $+(w)$ \\
\hline Oxidation of gluconate & + & - & - & + \\
\hline Reducing substance from sucrose & + & + & + & + \\
\hline Urease & + & - & - & $+(w)$ \\
\hline Arginine decarboxylase & $+(\mathrm{d})$ & $+(\mathrm{d})$ & $+(\mathrm{d})$ & $+(\mathrm{d})$ \\
\hline Lysine decarboxylase & - & - & - & - \\
\hline Ornithine decarboxylase & - & - & - & - \\
\hline Phenylalanine deaminase & + & + & + & - \\
\hline Growth in $3 \% \mathrm{NaCl}$ & + & + & + & + \\
\hline Growth in $4 \% \mathrm{NaCl}$ & \pm & \pm & \pm & \pm \\
\hline $\mathrm{KCN}$ inhibition & - & + & + & + \\
\hline Indole production & - & - & - & - \\
\hline Methyl red test & - & - & - & - \\
\hline Acetoin production & - & - & - & - \\
\hline $\begin{array}{l}\text { Guanine-plus-cytosine content of } \\
\text { deoxyribonucleic acid }\end{array}$ & $66-68 \mathrm{~mol} \%$ & $66 \mathrm{~mol} \%$ & $64 \mathrm{~mol} \%$ & $65-67 \mathrm{~mol} \%$ \\
\hline Tobacco hypersensitivity reaction & + & - & - & + \\
\hline Potato rot & - & - & - & - \\
\hline Pathogenicity on konjac & + & - & - & - \\
\hline Pathogenicity on watermelon & $-(\mathrm{HR})$ & - & - & + \\
\hline
\end{tabular}

$a+$, Positive; - , negative; \pm , slow; $(\mathrm{d})$, delayed reaction; $(w)$, weak reaction; $(\mathrm{HR})$, hypersensitive reaction; Alk, alkaline; 0 , oxidative.

${ }^{b}$ Each organism had one flagellum.

ria. All bacteria reduced nitrate to nitrite, but did not exhibit denitrification. All bacteria were weakly positive for arginine decarboxylase; i.e., the medium under oil turned purple within 5 to 7 days. Except for $P$. pseudoalcaligenes subsp. citrulli, the bacteria tested were positive for the phenylalanine deaminase reaction.

The konjac bacterium utilized D-ribose, Dfructose, ethanol, glycerol, and D-mannitol as sole sources of carbon, with production of acid.
Several amino acids and organic acids were also utilized. The kinds of substrates utilized were generally analogous to the kinds of substrates utilized by the members of the $P$. alcaligenes group; an exception was the utilization of $D$ mannitol by the konjac bacterium, which distinguished this organism from the other bacteria. $P$. pseudoalcaligenes subsp. citrulli utilized L-arabinose and D-galactose, and this characteristic enabled me to differentiate $P$. pseudoalcaligenes 
TABLE 3. Utilization of substrates by the konjac bacterium, $P$. alcaligenes, $P$. pseudoalcaligenes, and $P$. pseudoalcaligenes subsp. citrulli

\begin{tabular}{l|c|c|c|c}
\hline \multicolumn{1}{|c|}{ Substrate } & $\begin{array}{c}\text { Konjac } \\
\text { bacterium } \\
(n=17)\end{array}$ & $\begin{array}{c}\text { P. alcali- } \\
\text { genes } \\
(n=1)\end{array}$ & $\begin{array}{c}\text { P.pseudo- } \\
\text { alcali- } \\
\text { genes } \\
(n=1)\end{array}$ & $\begin{array}{c}\text { P. pseudo- } \\
\text { alcali- } \\
\text { genes } \\
\text { subsp. } \\
\text { citrulli } \\
(n=2)\end{array}$ \\
\hline L-Arabinose & $-a$ & - & - & + \\
D-Ribose & + & - & - & + \\
D-Galactose & - & - & - & + \\
D-Fructose & + & - & + & + \\
Ethanol & + & - & + & + \\
Glycerol & + & - & + & + \\
Propanol & + & - & + & + \\
D-Mannitol & + & - & - & - \\
Acetate & + & - & - & + \\
Lactate & + & + & + & + \\
Maleate & + & + & + & + \\
D-Malate & + & + & + & + \\
Fumarate & + & + & + & + \\
Succinate & + & + & + & + \\
Citrate & + & + & + & + \\
Malonate & + & - & - & + \\
Propionate & + & + & - & + \\
$n$-Caprate & + & + & + & + \\
DL-Tartrate & + & - & - & + \\
$\beta$-Alanine & + & + & + & + \\
L-Serine & + & + & + & + \\
L-Leucine & + & - & - & + \\
L-Isoleucine & + & - & - & + \\
$\gamma$-Aminobu- & + & + & + & + \\
tyric acid & + & & & + \\
\hline & + & + & + \\
\hline
\end{tabular}

${ }^{a}+$, Positive; - , negative; (d), delayed. The following compounds were not utilized by any of the bacteria: D-arabinose, D-xylose, D-glucose, D-mannose, Lrhamnose, cellobiose, maltose, lactose, trehalose, sucrose, melibiose, raffinose, melezitose, meso-erythritol, myo-inositol, ribitol, galactitol, glucitol, xylan, inulin, glycogen, starch, carboxymethyl cellulose, salicin, $\alpha$-methyl-D-glucoside, esculin, formate, oxalate, gluconate, glycolate, $n$-butyrate, sebacate, and hippurate.

subsp. citrulli from the other organisms in this study.

The strains of $P$. pseudoalcaligenes subsp. citrulli tested differed from the original description of this taxon in being positive for nitrate reduction and the tobacco hypersensitivity reaction.

Symptoms. The disease developed on leaf blades and leaf petioles in summer, causing severe leaf blight. The lesions in the early stage of disease development were water-soaked spots that were a few millimeters in diameter. These spots quickly enlarged to form lesions with an average size of 15 to $25 \mathrm{~mm}$ long by 5 to $10 \mathrm{~mm}$ wide. The lesions showed distinctive characteristics, such as a rectangular shape limited by veins, a dark green to brownish green discoloration, and evidence of water congestion. The lesions turned dark brown in several days, and their marginal areas were surrounded by yellow halos a few millimeters wide. When dried, the lesions became thin, transparent films with black veins. The disease was relatively mild under dry weather conditions, so that lesions limited by veins were individually scattered on the leaves. Under humid conditions, however, the size of the lesions rapidly increased, and frequently several lesions coalesced with each other, covering an entire leaf. Such leaves often rotted and dropped off, leaving naked stalks (Fig. 2).

Inoculation tests. (i) Konjac. The konjac bacterium produced characteristic symptoms when the spray inoculation method or the wound inoculation method or both were used. The first symptoms appeared 48 to $72 \mathrm{~h}$ after inoculation as small, water-soaked spots at the wound sites. The development of scattered spots followed 5 to 7 days after inoculation of a nonwounded leaf area. These spots enlarged to form rectangular lesions that were 10 to 20 by 2 to $4 \mathrm{~mm}$ in 1 week. The lesions were limited by veins and soon turned light brown to dark brown with yellow halos. The disease continued to progress, causing typical leaf blight. Soft rot of the diseased leaves was induced outdoors under rainy conditions in August to September but not in the greenhouse. No strain of $P$. alcaligenes, $P$. pseudoalcaligenes, or $P$. pseudoalcaligenes subsp. citrulli was pathogenic on konjac plants.

(ii) Cucurbitaceous plants. Strains of $P$. alcaligenes and $P$. pseudoalcaligenes failed to infect seedlings of watermelon, cucumber, muskmelon, and pumpkin. The konjac strains produced white lesions on the cotyledons 2 to 3 days after inoculation, but not on true leaves when the plants were inoculated by the pricking method.

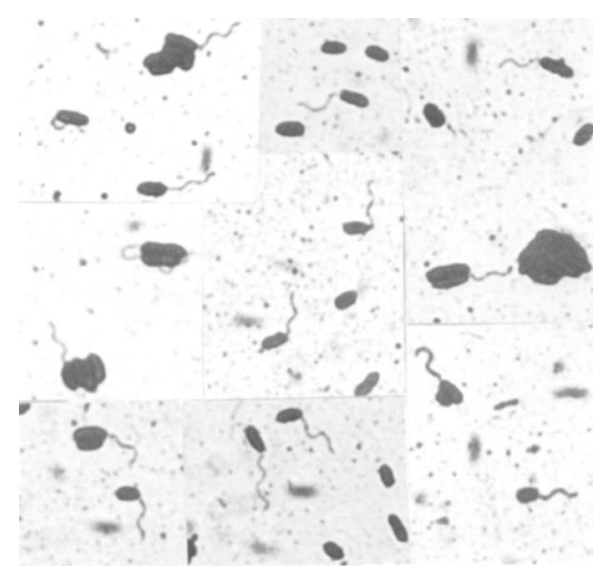

FIG. 1. Polar flagellation of strain $\mathrm{K} 2{ }^{\mathrm{T}} . \times 2,000$. 


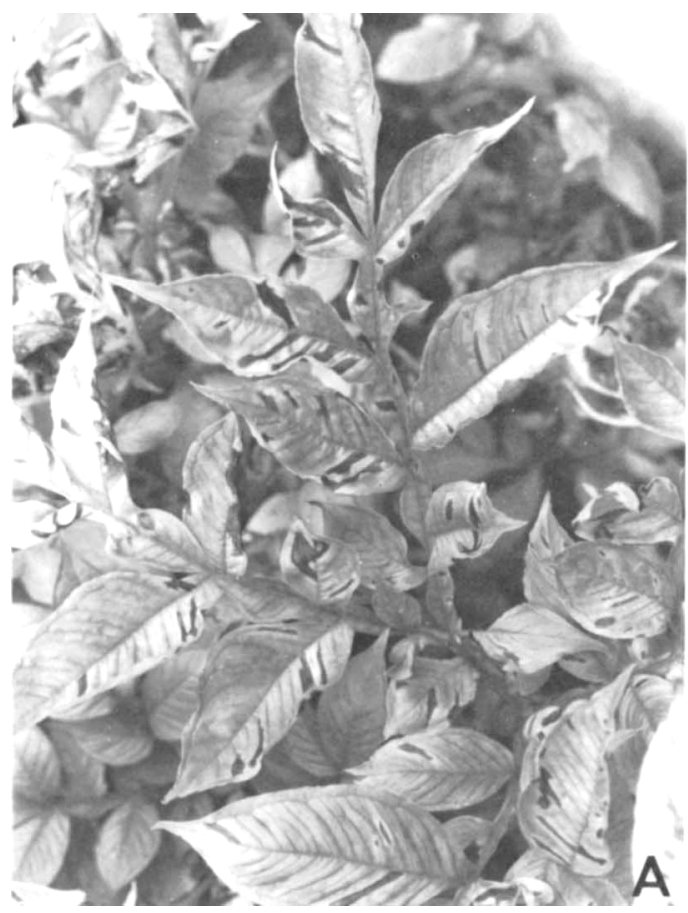

FIG. 2. Symptoms of bacterial leaf blight of konjac phase at the later stages.

Such lesions never became water soaked. Therefore, the white areas of dead tissue were considered to be due to a hypersensitive reaction and not to a pathogenic reaction (6). Two strains of $P$. pseudoalcaligenes subsp. citrulli produced water-soaked lesions on leaves, cotyledons, and hypocotyls of cucurbitaceous plants after a few days. The symptoms were identical to those described by Schaad et al. (10).

(iii) Hypersensitive reactions and potato rot. Strains of the konjac bacterium and $P$. pseudoalcaligenes subsp. citrulli produced positive hypersensitive reactions on tobacco leaves (Nicotiana tabacum cv. Bright Yellow) within $12 \mathrm{~h}$. No strain tested caused soft rot of potato slices.

\section{DISCUSSION}

Uyeda (17) described the symptoms of bacterial leaf blight of konjac as follows: "the leaves turn brown from the top and black brown later. The lesions enlarge to leaf lamina, which results in wilting and/or drooping within 2 to 3 weeks. In severe cases petioles are attacked, the leaves fall and the tuber shrivels or rots. The whole plant finally falls down on the ground." No mention was made of the presence of rectangular leaf spots limited by veins, which are the characteristic symptoms at the beginning of the disease. However, the description of Uyeda generally

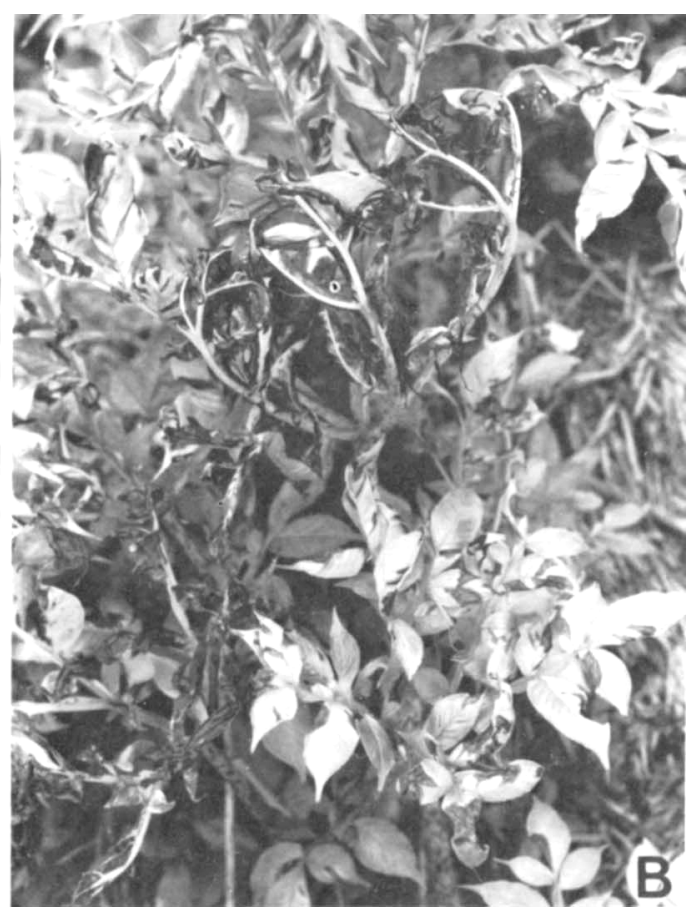

(A) Leaf spot phase at the early stages. (B) Leaf blight

agrees with the description of the severe form of the disease which I studied. Under humid conditions associated with frequent rain and high temperature, konjac plants become heavily infected, showing symptoms similar to those described by Uyeda. Moreover, no other bacterial disease has been detected on konjac plants, except soft rot caused by Erwinia carotovora subsp. carotovora. Therefore, I identified the disease which I observed as the bacterial leaf blight described by Uyeda in 1910 .

However, the bacterium that causes this disease appears to be entirely different from $X$. conjaci (Uyeda) Burkholder (1), although the properties of the latter were poorly defined. According to the original description of Uyeda, this bacterium showed the following characteristics: "gram-positive rods with 1 to 4 polar flagella; colonies white and then light yellow; gelatin liquefied; milk coagulated and peptonized; indole produced; $\mathrm{KNO}_{3}$ reduced; $\mathrm{H}_{2} \mathrm{~S}$ produced; gas from glucose; optimum temperature, $24^{\circ} \mathrm{C}$." It can be assumed from the symptoms which Uyeda described that isolation of the pathogen from plants had been attempted at the advanced stage of the disease. Therefore, it is possible that $X$. conjaci might have been a saprophytic bacterium which contaminated such old lesions.

The bacterium which I studied shares with the $P$. alcaligenes group the following phenotypic 
TABLE 4. Phenotypic characteristics that differentiate $P$. alcaligenes, $P$. pseudoalcaligenes, $P$. pseudoalcaligenes subsp. citrulli, and the konjac bacterium

\begin{tabular}{|c|c|c|c|c|}
\hline Character & $\begin{array}{c}\text { Konjac } \\
\text { bacte- } \\
\text { rium }\end{array}$ & $\begin{array}{l}\text { P.al- } \\
\text { cali- } \\
\text { genes }\end{array}$ & $\begin{array}{c}P . \\
\text { pseudo- } \\
\text { alcali- } \\
\text { genes }\end{array}$ & $\begin{array}{c}P . \\
\text { pseudo- } \\
\text { alcali- } \\
\text { genes } \\
\text { subsp. } \\
\text { citrulli }\end{array}$ \\
\hline $\begin{array}{l}\text { Poly- } \beta \text {-hydroxy- } \\
\text { butyrate }\end{array}$ & + & - & - & + \\
\hline Pigmentation & Brown & - & - & - \\
\hline Gelatin liquefaction & - & \pm & - & \pm \\
\hline Tween 80 hydrolysis & + & + & - & + \\
\hline Urease & + & - & - & $+(w)$ \\
\hline $\begin{array}{c}\text { Phenylalanine } \\
\text { deaminase }\end{array}$ & + & + & + & - \\
\hline $\mathrm{KCN}$ inhibition & - & + & + & + \\
\hline Utilization of: & & & & \\
\hline L-Arabinose & - & - & - & + \\
\hline D-Ribose & + & - & - & + \\
\hline D-Fructose & + & - & + & + \\
\hline Ethanol & + & - & + & + \\
\hline Glycerol & + & - & + & + \\
\hline D-Mannitol & + & - & - & - \\
\hline Malonate & + & - & - & + \\
\hline Propionate & + & + & - & + \\
\hline DL-Tartrate & + & - & - & + \\
\hline L-Leucine & + & - & - & + \\
\hline L-Isoleucine & + & - & - & + \\
\hline Propanol & + & - & + & + \\
\hline
\end{tabular}

${ }^{a}+$, Positive; - , negative; \pm , slow; (w), weak.

characteristics, which distinguish it from most other members of the genus Pseudomonas: single polar flagellum, positive oxidase reaction, no requirement for organic growth factors, no hydrolysis of starch, growth at $41^{\circ} \mathrm{C}$ but not $4^{\circ} \mathrm{C}$, utilization of lactate, caprate, and $\gamma$-aminobutyrate, but no utilization of D-glucose, cellobiose, sebacate, or gluconate (8). The differences among the four bacteria included in this study are summarized in Table 4 . The differences listed in Table 4 may have resulted from the limited number of strains used in this study, because it is known that both $P$. alcaligenes and $P$. pseudoalcaligenes are heterogeneous in many of their biochemical properties and are closely related to each other (8). The only character which distinguishes $P$. alcaligenes and $P$. pseudoalcaligenes is the utilization of fructose as a sole source of carbon. Moreover, some of the properties listed in Table 4 have not been tested and described previously.

Despite the diversity in the biochemical properties of $P$. alcaligenes and $P$. pseudoalcaligenes, I believe that the konjac bacterium should be included in P. pseudoalcaligenes because of its ability to utilize D-fructose as a sole source of carbon. However, the konjac strains differ from $P$. pseudoalcaligenes in plant pathogenicity, as well as in some biochemical properties, such as urease reaction, utilization of Dribose, D-mannitol, DL-tartrate, and malonate, brown pigmentation, and Tween 80 hydrolysis.

The konjac bacterium differs from the plantpathogenic organism $P$. pseudoalcaligenes subsp. citrulli in host range and other characters, such as utilization of $\mathrm{L}$-arabinose, $\mathrm{D}$-mannitol, and D-galactose, growth inhibition by $\mathrm{KCN}$, pigmentation, gelatin liquefaction, and phenylalanine deaminase.

On the basis of the differences mentioned above, I concluded that the konjac bacterium should be recognized as a separate subspecies of $P$. pseudoalcaligenes and should be named Pseudomonas pseudoalcaligenes subsp. konjaci subsp. nov.

A condensed description of $P$. pseudoalcaligenes subsp. konjaci is given below.

Pseudomonas pseudoalcaligenes subsp. konjaci subsp. nov. $P$. pseudoalcaligenes subsp. konjaci (kon.ja'ci. konjac name of host species; L. n. konjaci of konjac) cells are gram-negative rods $0.5 \mu \mathrm{m}$ wide by 1.8 to $2.3 \mu \mathrm{m}$ long, are motile by means of a single polar flagellum, and accumulate poly- $\beta$-hydroxybutyrate. Colonies on YP agar are white, round, transparent, smooth, slightly convex, and 2 to $3 \mathrm{~mm}$ in diameter after incubation for 5 days at $28^{\circ} \mathrm{C}$. A water-soluble brown pigment is produced on King medium B. Aerobic. Positive for nitrate reduction but negative for denitrification. Growth occurs at $41^{\circ} \mathrm{C}$ but not at $4^{\circ} \mathrm{C}$. Oxidase positive. Utilizes Dfructose, D-ribose, D-mannitol, glycerol, ethanol, several amino acids, and organic acids as sole carbon sources. No growth occurs with the other sugars and polysaccharides tested (Table 3). Tobacco hypersensitivity positive. Pathogenic on konjac $(A$. konjac). The guanine-pluscytosine content of the deoxyribonucleic acid is 66 to $68 \mathrm{~mol} \%$. Additional characteristics are listed in Table 2. Strain K2 is the type strain and has been deposited with the American Type Culture Collection as ATCC 33996 and with the Plant Diseases Division Culture Collection as PDDCC 7733.

\section{ACKNOWLEDGMENT}

I thank N. Hayashi, Gumma Agricultural Experiment Station, for providing cultures.

\section{LITERATURE CITED}

1. Breed, R. S., E. G. D. Murray, and A. P. Hitchens. 1948. Bergey's manual of determinative bacteriology, 6th ed. The Williams \& Wilkins Co., Baltimore.

2. Buchanan, R. E., and N. E. Gibbons (ed.). 1974. Bergey's manual of determinative bacteriology, 8th ed. The Williams \& Wilkins Co., Baltimore.

3. Cowan, S. T., and K. J. Steel. 1974. Cowan and Steel's manual for the identification of medical bacteria, 2nd ed. 
Cambridge University Press, Cambridge.

4. Dye, D. W. 1968. A taxonomic study of the genus Erwinia. I. The "amylovora group." N. Z. J. Sci. 11:590-607.

5. Dye, D. W., J. F. Bradbury, M. Goto, A. C. Hayward, R. A. Lelliott, and M. N. Schroth. 1980. International standards for naming pathovars of phytopathogenic bacteria and a list of pathovar names and pathovar strains. Rev. Plant. Pathol. 59:153-168.

6. Klement, Z., G. L. Farkas, and L. Lovrekovich. 1964. Hypersensitive reaction induced by phytopathogenic bacteria in the tobacco leaf. Phytopathology 54:474-477.

7. Marmur, J. 1961. A procedure for the isolation of deoxyribonucleic acid from microorganisms. J. Mol. Biol. 3:208218.

8. Ralston-Barrett, E., N. J. Palleroni, and M. Doudoroff. 1976. Phenotypic characteristics and deoxyribonucleic acid homologies of the "Pseudomonas alcaligenes" group. Int. J. Syst. Bacteriol. 26:421-426.

9. Schaad, N. W. (ed.). 1980. Laboratory guide for identification of plant pathogenic bacteria. American Phytopathological Society, Minneapolis, Minn.

10. Schaad, N. W., G. Sowell, Jr., R. W. Goth, R. R. Cowell, and R. E. Webb. 1978. Pseudomonas pseudoalcaligenes subsp. citrulli subsp. nov. Int. J. Syst. Bacteriol. 28:117125 .

11. Shirata, A., and M. Goto. 1981. Bacterial flagella staining by modified Yamanaka method. Shokubutsu Boeki 35:325-326 (In Japanese.)

12. Skerman, V. B. D., V. McGowan, and P. H. A. Sneath (ed.). 1980. Approved lists of bacterial names. Int. J. Syst. Bacteriol. 30:225-420.

13. Society of American Bacteriologists. 1957. Manual of microbiological methods. McGraw-Hill Book Co., Inc., New York.

14. Stanier, R. Y., N. J. Palleroni, and M. Doudoroff. 1966. The aerobic pseudomonads: a taxonomic study. J. Gen. Microbiol. 43:159-271.

15. Starr, M. P. 1946. The nutrition of phytopathogenic bacteria. I. Minimal nutritive requirements of the genus Xanthomonas. J. Bacteriol. 51:131-143.

16. Ulitzur, S. 1972. Rapid determination of DNA base composition by ultraviolet spectroscopy. Biochim. Biophys. Acta 272:1-11.

17. Uyeda, E. 1910. The pathogen of bacterial leaf blight of konjac plant, and the mannan-liquefying bacteria. Bot. Mag. 24:177-182. (In Japanese.) 